\title{
Alberta's OIL SANDS: An UnSECURED ASSET? An Analysis of the Mine Financial Security Program in Relation to Surface Mining of The Alberta OIL SANDS
}

\author{
MiCHELLE COOK*
}

\begin{abstract}
This article conducts a comprehensive review of Alberta's Mine Financial Security Program (MFSP), the provincial program that governs the collection of financial assurance for reclamation liabilities (also known as "reclamation liability security," "financial reclamation sureties," or "closure bonds"). This article assesses the MFSP program in relation to surface oil sands mining. It concludes that while the recently implemented MFSP has improved some aspects of the oil sands reclamation security regime, Alberta's MFSP still suffers from issues of transparency, inadequate collection of financial security, and utilization of underinclusive classifications of environmental liabilities. Moreover, this article analyzes the particular risk that oil sands assets have of "stranding" (namely, being unanticipatedly or prematurely written off, downwardly revalued, or converted to a liability) as well as how stranding would impact Alberta's financial assurance regime.
\end{abstract}

This article concludes that while the oil sands are at a heightened risk for asset stranding compared to the international oil industry as a whole, international oil and gas assets are unlikely to become completely stranded. This article also finds that investors have likely already priced the risk of asset stranding at 1.5-2 percent and will be unlikely to readjust their portfolios unless divestment campaigns strengthen or environmental legislation becomes more certain. The MFSP uses a method that does not account for large fluctuations in oil prices, nor does it sufficiently account for the risk of partial stranding. If asset stranding were to occur, the only way the Alberta government would be able to afford the costs of reclamation would be to paradoxically develop the very resource that was defaulted on, against the environmental legislation or political pressures that caused the stranding.

\section{TABLe of Contents}

I. INTRODUCTION . . . . . . . . . . . . . . . . . . . . . . . . . 177

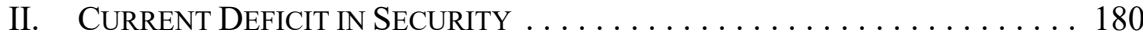

III. The New 2011 Mine Financial SEcurity Program . . . . . . . . . . 181

A. Current Levels of TransParency . . . . . . . . . . . 182

B. InSUFFICIENT FinANCIAL SECURITY $\ldots \ldots \ldots \ldots \ldots \ldots \ldots \ldots$

C. The Definition of Reclamation Does Not

ACCOUNT FOR BROADER ENVIRONMENTAL LIABILITIES . . . . . . . 194

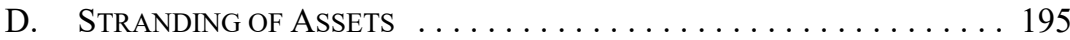

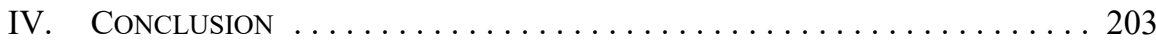

\section{INTRODUCTION}

For the past two years, Alberta's oil sands have been going through a period of serious financial difficulty. Starting in 2015, major oil producers announced they would no longer be expanding in the oil sands while Shell cut its $\$ 7.25$ billion stake in Alberta's oil sands in 
March 2017. ${ }^{1}$ The severe Fort McMurray fire in 2016, one of Canada's costliest disasters at $\$ 9.9$ billion, only compounded the difficulties Alberta's oil sands were facing. ${ }^{2}$ This trend is followed by oil giant Exxon Mobil's $\$ 16$ billion removal from the Kearl Oilsands project and ConocoPhillips stating that their oil sands barrel output was at a 15 -year low. ${ }^{3}$ The world is facing lower oil prices and tighter restrictions on carbon. With many companies withdrawing from the oil sands, which has some of the highest costs of production for oil, it leaves many Canadian citizens wondering who will bear the cost of the mines' ecological destruction.

In order to access and extract a desired resource, mining operations change the land and surrounding environment. In order to mitigate some of the damage that has been done, companies are under a legal obligation to reclaim the land disturbed in the mining process. ${ }^{4}$ Therefore a "reclamation liability" is the future liability a company holds to restore the land to the standards set by the provincial government. "Reclamation" under the statute includes responsibility to carry out suspension, abandonment, remediation, and surface reclamation. ${ }^{5}$ While the oil sands are rarely reclaimed to their prior state, ${ }^{6}$ legislative standards should be set at a level that can restore healthy ecosystems. One way of defining "reclamation" is as "the process of reconverting disturbed land to its former or other productive uses."

The necessity of having a strong reclamation financial assurance regime can be seen by Canada's large "reclamation deficit," which was allowed to occur under the previous oil sands reclamation security program. ${ }^{8} \mathrm{~A}$ "reclamation deficit" means the pace and scale of oil sands mining has been increasing much faster than on-the-ground reclamation. In 2017, Alberta had 475,000 hectares of current mineable deposits, not including toxic tailing ponds. ${ }^{9}$ In 2009, Alberta had the same level of mineable deposits. ${ }^{10}$ At that time, despite the industry claiming that 11 percent of the land impacted by oil sands activity had been reclaimed, an independent study found that only 0.16 percent of the land, or 104 hectares had been certified as reclaimed. ${ }^{11}$ With that being said, the industry has increased its reclamation and research and development budgets due to burgeoning public knowledge about the impact of oil sands mining. ${ }^{12}$

Rakteem Katakey \& Amanda Jordan, "Shell Cuts Debt with \$7.25 Billion Sale of Canada Oil Sands," Bloomberg (9 March 2017), online: <https://www.bloomberg.com/news/articles/2017-03-09/shellagrees-to-sell-oil-sands-operations-for-7-25-billion>. Bob Weber, "Costs of Alberta Wildfire Reach \$9.5 Billion: Study," BNN Bloomberg (17 January 2017), online: <https://www.bnn.ca/costs-of-alberta-wildfire-reach-9-5-billion-study-1.652292>.

Katakey \& Jordan, supra note 1.

Environmental Protection and Enhancement Act, RSA 2000, c E-12, s 137(1) [EPEA].

Ibid, s 1 (ddd).

Kevin P Timoney, Impaired Wetlands in a Damaged Landscape: The Legacy of Bitumen Exploitation in Canada (Cham, Switzerland: Springer, 2015) at 155-60.

See Alberta Environment, "Native Prairie Reclamation," by Heather M Sinton (Edmonton: Alberta Environment, 2011), online: $<$ www.albertapcf.org/rsu_docs/pcf_recl-update_final_110917.pdf $>$. Nathan Lemphers, Simon Dyer \& Jennifer Grant, "Toxic Liability: How Albertans Could End Up Paying for Oil Sands Mine Reclamation," (Drayton Valley: The Pembina Institute, 2010) at 12.

9 Alberta Energy, "Alberta's Leased Oil Sands Area" (Edmonton: Resource Mapping \& Analysis, September 2017).

10 Alberta Energy, “Alberta's Leased Oil Sands Area” (Edmonton: Resource Mapping \& Analysis, 24 June 2009).

Lemphers, Dyer \& Grant, supra note 8 at 39.

Ibid at 12 . 
Reclamation liabilities are the easiest way to ensure that oil sand operators are held legally accountable for some of the environmental liabilities their activities create. First, unlike climate change due to greenhouse gas emissions, the environmental impact and liability for reclamation is directly attributable to a particular mine. Second, the level of damage that has been caused by mining activity has a precise, quantifiable number for reclamation liabilities: the amount to restore the land to an equivalent pre-mining capacity, as determined via a third-party bidding process or the company's (or the government's) own reclamation efforts. As governments are responsible for environmental protection, they need to find a balance between minimizing the risk of undertaking reclamation costs while maintaining an investorfriendly climate, keeping in mind that the uncertainties and expenses of oil exploration and the large financial assurance requirements both serve as a deterrent. ${ }^{13}$

After the government of Alberta facilitated numerous multi-stakeholder oil sands initiatives, such as the province-wide Land-Use Framework and Lower Athabasca Regional Plan, it developed a new reclamation security regime called the Mine Financial Security Program (MFSP) as part of its 2011 Oil Sands Progressive Reclamation Strategy. ${ }^{14}$ This article is the first post-implementation evaluation of the MFSP, on the basis of transparency, level of financial security, and classification of environmental liabilities. Moreover, this article conducts an innovative analysis by noting that the financial assurance for reclamation liabilities is based on assets that may become "stranded" (that is, will suffer from unanticipated or premature write offs, downward revaluations, or conversion to liabilities) and analyzes the particular stranding risk that oil sands assets face. Ultimately, this article concludes that while the government of Alberta has made some headway in addressing concerns about oil sand operators' reclamation liabilities, there are transparency issues that make the assessment of the amount of financial security collected difficult.

The MFSP was incorporated into the Conservation and Reclamation Regulation pursuant to section 16.1. ${ }^{15}$ While not the concern of this article, both the EPEA ${ }^{16}$ and the Activities Designation Regulation, ${ }^{17}$ also apply to reclamation obligations but do not deal with its security program. The Orphan Well project, an Alberta government project to manage the abandonment of upstream oil and gas orphan wells, pipelines, and facilities, is also outside the scope of this article. It should be noted that remediation is different than reclamation: remediation is "taking action to reduce, isolate, or remove contamination from an environment with the goal of preventing exposure to people or animals." 18 While remediation and reclamation are often considered together, this article focuses solely on reclamation.

For more information on this balancing, see C George Miller, Financial Assurance for Mine Closure and Reclamation: A Study Prepared for the International Council on Mining and Metals (London, UK: International Council on Mining and Metals, 2005).

Adam Wellstead, Jeremy Rayner \& Michael Howlett, “Alberta's Oil Sands Reclamation Policy Trajectory: The Role of Tense Layering, Policy Stretching, and Policy Patching in Long-term Policy Dynamics" (2016) 59:10 J Environmental Planning \& Management 1873 at 1874.

Alta Reg 115/1993, s 16.1 [CRR].

Supra note 4.

Alta Reg 276/2003.

Wellstead, Rayner \& Howlett, supra note 14 at 1880. 


\section{CurRent Deficit In SECURITY}

Understanding that some companies may be unwilling or unable to pay for reclamation costs, security deposits are taken by the provincial government to prevent companies from simply defaulting on their future reclamation obligations after all the wealth has been extracted from the land. In a way, security deposits are a "surety" or "guarantee" that the public will not bear the cost of restoring the land. ${ }^{19}$ Should the company be unwilling to reclaim the land or comply with the Alberta Energy Regulator's (AER) orders, the company forfeits its security. ${ }^{20}$ Moreover, the company is liable for any additional costs the government incurs to reclaim the land. ${ }^{21}$

Oil sand companies operating in Alberta are legally required to provide financial security and carry insurance for their activities on the land. ${ }^{22}$ Presently, not a single oil sands company has paid their reclamation liability obligation in full, although this is in no way precluded under the current security program. ${ }^{23}$ This is normal and largely due to the fact that reclamation costs require a large capital expenditure, vary throughout the operation of the mine, and the future cost to fully reclaim a mine is largely uncertain.

Alberta's regime for collecting financial assurance for reclamation liabilities is the MFSP. It currently suffers from four inadequacies: (1) lack of transparency, (2) potentially insufficient amounts of security collected, (3) a narrow definition of environmental liabilities, and (4) a failure to take into account that the assets upon which the security is taken may become "stranded" due to climate change legislation and international oil prices. Despite the growing public concern about the environmental impacts of the oil sands, ${ }^{24}$ only three comprehensive academic reports exist for the evaluation of the sufficiency of security for oil sands' reclamation liabilities. ${ }^{25}$ The latest report was written in 2011, before the MFSP was fully implemented or transferred from Environment Alberta to the AER. None of these reports accounted for "asset stranding." In 2009, under the previous reclamation regime, the estimated total cost to reclaim the land disturbed by oil sands was between $\$ 10$ and $\$ 15$ billion, which meant the government's total oil sands security had an estimated shortfall of approximately $\$ 9.180$ to $\$ 14.180$ billion. ${ }^{26} \mathrm{Had}$ the Alberta government pursued reclamation, the cost to Alberta taxpayers would have been $\$ 4,300$ to $\$ 6,300$ each. ${ }^{27}$ The government's

Alberta Energy Regulator, “Mine Financial Security Program,” online: $<$ https://www.aer.ca/regulatingdevelopment/project-closure/liability-management-programs-and-processes/mine-financial-securityprogram> [AER, “MFSP"].

CRR, supra note 15 , s $24(1)$.

EPEA, supra note 4, ss 245(1)-(2).

Ibid, s 135(1).

Auditor General of Alberta, Report of the Auditor General of Alberta: July 2015 (Edmonton: OAG, 2015) at 35 [AG Report 2015].

A poll done by Ekos Research found 60 percent of the 1,800 Albertans surveyed believed the provincial government does not enforce environmental rules on the oil sands very strictly. A total of 70 percent of respondents said the government should be tougher (The Canadian Press, "Albertans Want Tighter Oilsands Environmental Enforcement: Poll," National Observer (2 October 2015), online $<$ https://www. nationalobserver.com/2015/10/02/news/albertans-want-tighter-oilsands-environmental-enforcementpoll $>$ ).

25 See Lemphers, Dyer \& Grant, supra note 8; Chrysten Perry \& Craig Saloff, "Oil Sands Mining Reclamation in Alberta: A Discussion of the Prior Regime and the New Mine Financial Security Program" (2011) 49:2 Alta L Rev 277; U Thorley, "Mine Reclamation Costs in the Alberta Oil Sands" (2012) 64:8 Mining Engineering 93. Lemphers, Dyer \& Grant, ibid at 7. Ibid. 
prior trend of implementing inadequate financial assurance regimes makes reviewing financial security programs even more pressing.

\section{The New 2011 Mine Financial Security Program}

As previously alluded to, the reclamation liability security program was notably changed by the new MFSP implemented in 2011. Jurisdiction for security deposit management was transferred from Environment Alberta to the newly-created AER in March 2014. Interestingly, when the MFSP was being developed, environmental groups were not consulted because the program was deemed to be a financial policy, not an environmental policy. ${ }^{28}$

The main change of the MFSP was it removed the previous full security approach (in which full security was collected based on the estimated reclamation obligations an operator would have at the end of the year) and replaced it with an asset-to-liability approach. In brief, the MFSP has a level of base security for each operator dependent on the type of mine, regardless of the size of the mine (in hectares). ${ }^{29}$

\section{TABLE 1:}

Mine Financial Security Program ${ }^{30}$

\begin{tabular}{|l|c|}
\multicolumn{1}{|c|}{ New Mines - Mine Type } & Base Security Deposit (BSD) \\
\hline Mine-mouth coal mine & $\$ 2,000,000$ \\
\hline Export coal mine & $\$ 7,000,000$ \\
\hline $\begin{array}{l}\text { Oil sands mine with no EPEA approval as of } \\
\text { 1 January 2011 }\end{array}$ & $\$ 30,000,000$ \\
\hline $\begin{array}{l}\text { Oil sands mine and upgrader with no EPEA } \\
\text { approval as of 1 January 2011 }\end{array}$ & $\$ 60,000,000$ \\
\hline
\end{tabular}

Under the MFSP, additional security is required if an operator has (1) MFSP assets less than three times larger than its MFSP liabilities ("Asset Safety Factor Deposits"), (2) is less than 15 years from the end of its reserves ("Operating Life Deposits"), or (3) is not following its operator proposed but AER approved targeted reclamation plans ("Outstanding Reclamation Deposit"). ${ }^{31}$ Future work planned but not performed is accounted for at $\$ 75,000$ per hectare. $^{32}$ at 5-6, 11-149 [MFSP Standard]; AER, "MFSP," supra note 19.

Alberta Energy Regulator, Guide to the Mine Financial Security Program (Calgary: AER, 2017) at 20, online: <www.aer.ca/documents/liability/MFSP_Guide.pdf> [MFSP Guide 2017]. 
Besides the change in the approach to security determination, notable changes were made to the ability to use reclamation security deposits for government-led reclamation at other sites, ${ }^{33}$ requiring a CEO, CFO, or other financial executive to sign off on the reclamation report, and requiring mine operators to report the lifespans of all operational assets (however, lifespan information remained confidential). ${ }^{34}$ After reviewing the security regime prior to the MFSP, a 2010 Pembina Report made six key formal recommendations to increase the sufficiency of the security taken for reclamation liabilities: (1) convene public consultations on reclamation security deposits, (2) "[p]rovide online access to reclamation security calculations," (3) "[r] equire third-party verification of mine liability estimates," (4) expand liability coverage, (5) “[c]reate a staged reclamation certification process" and (6) "[e]nhance liability disclosure in company annual public financial reports." 35 Of these six recommendations, only two areas, staged reclamation certification processes and enhanced liability disclosure in the company's annual public financial reports (via requiring the CFO to sign off on reclamation liabilities), have been partially publicly addressed. ${ }^{36}$

\section{A. CurRent LeVEls OF Transparency}

It is evident that the Alberta government has been taking seriously the initiative to enhance the information about the criteria used to assess the overall reclamation liability. The current Annual Mine Financial Security Program Submissions report, released on a yearly basis, discloses the EPEA approval holder, the project(s) name(s) of that approval holder, the EPEA approval number, the total financial security held for that holder, the asset safety factor (required to be above three), and the (self-reported) completed reclamation by that holder, in hectares, in the previous year. ${ }^{37}$ The majority of this information was not disclosed under the previous financial assurance program. Furthermore, oil sands operators are "required to file a brief annual report that discloses their conservation and reclamation liability, their resource assets and the components of the resource asset calculation, and the amounts required for each security deposit under the program" to the AER, however not all of this information is made public. ${ }^{38}$ In comparison, disclosure is available monthly for the separate Liability Management Rating (LMR) program, which lists the deemed asset to deemed liability ratios for licensees in all Liability Management programs. ${ }^{39}$ The monthly LMR report further breaks down which licensees are over or below industry thresholds, the amount of licensees in each LMR range,and the aggregate security held in LMR programs. ${ }^{40}$

Alberta Energy Regulator, Directive 068: ERCB Security Deposits (Calgary: AER, 2010) at 4, online: $<$ https://www.aer.ca/documents/directives/Directive068.pdf $>$ [Directive 068].

MFSP Guide 2017, supra note 30 at 4; Certification of Disclosures in Issuers' Annual and Interim Filings, OSC NI 52-109 (2015). Also, the United States Sarbanes-Oxley Act (officially known as the Public Company Accounting Reform and Investor Protection Act of 2002, Pub L No 107-204, 116 Stat 745 (2002)) mandates this CEO/CFO auditing statement for United States securities issuers and many Canadian companies follow this law by practice.

Lemphers, Dyer \& Grant, supra note 8 at 9.

Ibid.

Alberta Energy Regulator, “Annual Mine Financial Security Program Submissions" (Calgary: AER, 2017).

AG Report 2015, supra note 23 at 31.

Alberta Energy Regulator, "Liability Management Rating and Reporting," online: $<$ https://www.aer.ca/ regulating-development/project-closure/liability-management-programs-and-processes/liabilitymanagement-rating-and-reporting $>$. Ibid. 
Lacking under the MFSP is a disclosure of precisely what factors were accounted for in each mine's security assessment and the process for quantifying that particular mine's liability. With that being said, there is some guidance on what is taken into account based on the AER's website, the July 2015 Auditor General's Report, and the CRR. First, information on how the asset-to-liability ratios and deviations from base security are calculated (discussed above), as well as the formula for calculating "assets" is available on both the AER website and broken down in the Auditor General report. ${ }^{41}$ Furthermore, the CRR states the amount of security is based on

(a) the estimated costs of conservation and reclamation submitted by the operator,

(b) the nature, complexity and extent of the activity,

(c) the probable difficulty of conservation and reclamation, giving consideration to such factors as topography, soils, geology, hydrology and revegetation, and

(d) any other factors the Director considers to be relevant. ${ }^{42}$

AER directives provide a more detailed description of what factors are taken into account for mining reclamation. For example, Directive 001 states:

\begin{abstract}
An estimate of surface reclamation costs must be based on an approach that returns the ability of the land to support land uses that are similar, but not necessarily identical, to that which existed before development of the site. This includes stabilization, contouring, conditioning, reconstruction, revegetation, and maintenance of the land and removal of the access road and directly related infrastructure (cattle guards, culverts, or bridges). If applicable, costs must also include all administrative and related tasks needed to obtain a reclamation certificate, such as a detailed site assessment, certificate application, and on-site inspection. $^{43}$
\end{abstract}

\title{
Directive 001, goes on to say that an operator must
}

[1] [excavate], to the extent possible, all affected soil and subsoil in order to meet or exceed applicable guidelines; [2] [treat or dispose] of oilfield waste at approved waste management facilities or, where oilfield waste and site characteristics warrant, [follow] ERCB requirements for on-site oilfield waste management; and [3] [treat] affected water, groundwater, bedrock, and inaccessible soil contamination to meet applicable guidelines, criteria, or standards. ${ }^{44}$

Moreover, there are several statutory obligations that require an operator or Minister to disclose information to the public. However, many of these requirements are vaguely written and do not do much to increase transparency. For example, under the EPEA, the Minister is required to report on the Environmental Protection Security Fund, ${ }^{45}$ the prior security regime 
(it is assumed that this obligation has transferred over to the new MFSP program). However, under the previous regime even minimal disclosure of only overall security levels was deemed sufficient to fulfill this legal obligation.

Ultimately, while there is some guidance about what the AER takes into account when determining the amount of security needed, this does not change the fact that the amount of reclamation liability is based on the operator's own self-assessments until verified by an AER audit. The operator's assessment does not need to be certified by an accountant nor does supporting documentation need to be provided. ${ }^{46}$ However, the MFSP limits the type of people that can conduct a reclamation liability assessment. Directive 001 states that sitespecific liability assessments (SSLAs) must be "conducted only by appropriately trained and experienced [SSLA] personnel." ${ }^{47}$ There are higher requirements for who can be a supervisor:

\footnotetext{
The assessment must be supervised and signed by a lead assessor who has completed post-secondary education in a directly related discipline and has prior experience estimating site-specific costs for suspension, abandonment, or reclamation. The lead assessor must also be a member in good standing of an association regulated by a professions or societies act of Alberta or be certified in Canada to conduct environmental site assessments by an agency that provides a comparable degree of professional accountability. $^{48}$
}

Directive 006 places a further requirement that a company must use an "assessment meeting Canadian Institute of Chartered Accountants (CICA) standards that is provided by the licensee and accepted by the AER."49 Contrary to previous reports, it appears that the AER does in fact place standards on who can compile and supervise the operator's reclamation reports. Considering that the amount of reclamation liabilities are typically in the millions, it is not too onerous to expect the AER to set out a strict definition of what constitutes "appropriate training" or mandate that a professional accountant needs to audit the assessment. On the whole, this article commends the government for their strong improvement in this area.

However, the security program's allowance of self-reporting is not advisable, especially because there is prior noted inadequate monitoring by the AER. ${ }^{50}$ For reasons unexplained, the MFSP removed the previous requirement that operators must provide detailed support for their calculations of the amount of security provided. ${ }^{51}$ Financial assurance is released back to the company based on their own reported reclamation, not upon government certified results. ${ }^{52}$

AG Report 2015, supra note 23 at 31-32.

Directive 001, supra note 43 at 7.

Ibid.

Alberta Energy Regulator, Directive 006: Licensee Liability Rating (LLR) Program and Licence Transfer Process (Calgary: AER, 17 February 2016) at 23, online: <https://www.aer.ca/documents/ directives/Directive006.pdf $>$ [Directive 006].

See AG Report 2015, supra note 23.

Ibid at 32.

Lemphers, Dyer \& Grant, supra note 8 at 19. 
The AER audits both the sufficiency of the posted security and the completed reclamation. As of July 2015, the AER had only completed three level 3 audits and two level 4 audits. ${ }^{53}$ Lower level audits are essentially basic phone conversations or written questions and answers. Only level 3 and 4 audits involve verifying the supporting information submitted by operators. ${ }^{54}$ The current rate of auditing is one level 3 audit and one level 4 audit per year. ${ }^{55}$ Alberta currently has eight oil sands mines that collectively post $\$ 939$ million of security, ${ }^{56}$ down from the $\$ 1.17$ billion in security in $2014 .{ }^{57}$ Given the staggering amount of risk, the provincial government should work towards improving their auditing mechanisms.

The government refuses to disclose per-mine security deposits, citing corporate confidentiality. From a business perspective, it is understandable that operators may wish to keep the breakdown of their reclamation liabilities secret. Reclamation is typically carried out by third parties who bid on these extremely lucrative reclamation contracts. However, there is a strong corresponding public interest in restoring the land as well as a high financial risk. Therefore, government verification should be preferred over industry self-reporting. Furthermore, it would not impact the confidential information of a particular mine for the AER to disclose precisely what criteria it used in reaching an operator's total reclamation security figure, as the criteria would apply to all operators. There is strong tension between corporate confidentiality and public disclosure in this area.

There are numerous reasons why the lack of transparency in the MFSP remains important. The main reason is that the mining industry has a long history of underestimating reclamation costs and therefore reliance on self-reporting should be viewed with skepticism. ${ }^{58}$ There is long-standing evidence that corporate environmental disclosures are primarily "selective, self-laudatory, and public relations driven. ${ }^{" 59}$ Reclamation liabilities are different than many other environmental liabilities because they need to be disclosed to the government. In spite of the total posted security amount being publicly available, the reclamation cost the operator has attributed to each of its specific mining operations or each reclamation activity is not publicly available. The inability to see disaggregated disclosures prevents both risk-adverse investors and the public from assessing the different levels of risk associated with each production type. There is strong evidence that if information is published in public outlets, disclosures will voluntarily be closer to the actual amounts required to restore the land. ${ }^{60}$

\section{B. INSUFFICIENT FinANCIAL SECURITY}

As mentioned above, the MFSP changed the security requirements so that there is a base amount of security posted based on the type of oil sands mine and then expenses are added

AG Report 2015, supra note 23 at 32.

Ibid.

Ibid.

Alberta Energy Regulator, "Annual Mine Financial Security Program Submissions" (Calgary: AER, 2017), online: $<$ https://www.aer.ca/documents/liability/AnnualMFSPSubmissions.pdf $>$.

Ibid.

Lemphers, Dyer \& Grant, supra note 8 at 14.

Yue Li \& Bruce J McConomy, "An Empirical Examination of Factors Affecting the Timing of Environmental Accounting Standard Adoption and the Impact on Corporate Valuation" (1999) 14:3 J Accounting, Auditing \& Finance 279 at 288.

Ibid at $298,309$. 
to that base amount based on the operator's asset to liability ratio ("Asset Safety Factor Deposit"), the lifespan of the mine ("Operating Life Deposit"), and the operator's compliance with its AER-approved reclamation plan ("Outstanding Reclamation Deposit"). ${ }^{61}$ The base amount approach makes it difficult to assess the sufficiency of the current formula for reclamation security.

This report points to the Auditor General of Alberta's statements, who, after reviewing confidential information, determined that the current level of security is inadequate to cover future reclamation costs. The 1998-99, ${ }^{62} 2000-2001,{ }^{63} 2005-2006,{ }^{64}$ April 2009, ${ }^{65}$ April $2010,{ }^{66}$ October $2010,{ }^{67}$ A pril $2011,{ }^{68}$ November $2011,{ }^{69}$ October $2012,{ }^{70}$ October $2013,{ }^{71}$ July $2014,{ }^{72}$ October 2014, ${ }^{73}$ July $2015,{ }^{74}$ October $2015,{ }^{75}$ and October $2016^{76}$ reports of the Auditor General of Alberta have commented on the deficiencies in reclamation security and issues with monitoring timely compliance of reclamation obligations. However, the October 2017 report of the Auditor General of Alberta classified an evaluation of the sufficiency of financial security as "implemented — to be confirmed with follow-up audits." 77 While no public information exists about major changes to oil sands reclamation financial assurances beyond the 2014 implementation of the MFSP, it is clear that the government believes the risk-based plan under the MFSP is sufficient for collecting security and that it should be maintained in a monitoring and verification stage.

AER, "MFSP," supra note 19.

Auditor General of Alberta, Annual Report of the Auditor General of Alberta: 1998-99 (Edmonton: OAG, 1999) at 158.

Auditor General of Alberta, Annual Report of the Auditor General of Alberta: 2000-2001 (Edmonton: OAG, 2001) at 16.

Auditor General of Alberta, Annual Report of the Auditor General of Alberta: 2005-2006, vol 1 (Edmonton: OAG, 2006) at 124; Annual Report of the Auditor General of Alberta: 2005-2006, vol 2 (Edmonton: 2006) at 86-89.

Auditor General of Alberta, Report of the Auditor General of Alberta: April 2009 (Edmonton: OAG, 2009) at $111,118$.

Auditor General of Alberta, Report of the Auditor General of Alberta: April 2010 (Edmonton: OAG, 2010) at 72, 208.

Auditor General of Alberta, Report of the Auditor General of Alberta: October 2010 (Edmonton: OAG, 2010) at 212, 214, 227.

Auditor General of Alberta, Report of the Auditor General of Alberta: April 2011 (Edmonton: OAG, 2011) at 97-98, 113 .

Auditor General of Alberta, Report of the Auditor General of Alberta: November 2011 (Edmonton: OAG, 2011) at 150 .

Auditor General of Alberta, Report of the Auditor General of Alberta: October 2012 (Edmonton: OAG, 2012) at $169-70$.

Auditor General of Alberta, Report of the Auditor General of Alberta: October 2013 (Edmonton: OAG, 2013) at 114-16.

Auditor General of Alberta, Report of the Auditor General of Alberta: July 2014 (Edmonton: OAG, 2014 ) at $4,51$.

Auditor General of Alberta, Report of the Auditor General of Alberta: October 2014 (Edmonton: OAG, 2014) at 130 .

AG Report 2015, supra note 23 at 5, 25-35.

Auditor General of Alberta, Report of the Auditor General of Alberta: October 2015 (Edmonton: OAG, 2015) at 93.

Auditor General of Alberta, Report of the Auditor General of Alberta: October 2016 (Edmonton: OAG, 2016) at 106.

Auditor General of Alberta, Report of the Auditor General: October 2017 (Edmonton: OAG, 2017) at $12,14$. 
1. Calculation of EPEA

APPROVAl HOLDERS’ SECURITY PER HECTARE

This article seeks to provide a rough numerical value of the amount of security posted by EPEA approval holders per hectare. While previous assessments of oil sands reclamation security have been based on a per hectare approach, ${ }^{78}$ the new MFSP does not vary based on the size of the mine. A per hectare approach makes the historical evaluation of the sufficiency of the MFSP easier to track as mining operations expand and more players enter the market. Oil sands mines do not have a high degree of variation, making cost comparisons possible. ${ }^{79}$ The average industry cost to reclaim an oil sands mine ranges from $\$ 10,000$ to $\$ 250,000$ per hectare.$^{80}$ For reference, it was publicly stated that a $\$ 45,000$ to $\$ 75,000$ per hectare baseline was used to develop the MFSP. ${ }^{81}$ If this base line was utilized, the amount posted by the MFSP could be at adequate levels to restore the land.

The cost of reclamation can dramatically change based on the location of the mine, the amount and seasonal distribution of precipitation, the types of covers for tailings impoundments, and other environmental factors. ${ }^{82}$ Dry landscape reclamation is fairly routine in the industry and the price typically falls within average per hectare ranges. ${ }^{83}$ This is because it is common practice to remove the nutrient rich top-soil before commencing open pit mining, which is stored off-site then returned when the land is ready to be reclaimed. ${ }^{84}$ Native species are then planted in the soil and are indefinitely monitored until they can be certified reclaimed. While the process is comparatively simple, it can take decades to complete, which accounts for the fact that there is only one certified reclaimed site in Alberta (as of writing). ${ }^{85}$

In contrast, wetland reclamation, which encompasses a high percentage of oil sands deposits, is still not economically feasible. For example, a 2010 Pembina report listed an experimental reclamation by Syncrude in a low-lying bog as costing $\$ 926,000$ per hectare. ${ }^{86}$ While this amount is very atypical, it indicates that oil sands operators cannot reclaim these areas at a lower cost with current technology. Even with that steep price, a study by Rebecca Rooney and Suzanne Bayley found that attempted oil sands reclamation in wet landscapes failed to match the species diversity and functionality of natural wetlands in the region. ${ }^{87}$ There is now a combined effort between the government, industry, and non-governmental organizations to fund research on reclaiming different wet landscapes.

Lemphers, Dyer \& Grant, supra note 8 at 32.

Li \& McConomy, supra note 59 at 283; ibid.

Wellstead, Rayner \& Howlett, supra note 14 at 1879.

Perry \& Saloff, supra note 25 at 296.

Boxi Shen, Study on Financial Assurance and Closure Cost for Mine Reclamation (MASc Thesis, University of British Columbia, Faculty of Graduate and Postdoctoral Studies, 2016) [unpublished] at 6.

Wellstead, Rayner \& Howlett, supra note 14 at 1879.

Ibid.

Ibid.

Lemphers, Dyer \& Grant, supra note 8 at 34.

Rebecca C Rooney \& Suzanne E Bayley, "Setting Reclamation Targets and Evaluating Progress: Submersed Aquatic Vegetation in Natural and Post-Oil Sands Mining Wetlands in Alberta, Canada" (2011) 37:4 J Ecological Engineering 569. 
The amount of security held by each EPEA approval holder per hectare was obtained by taking the financial security amount listed in the 2017 Annual MFSP Submission and dividing it by the amount of approved hectares in each operator's oil sands project.

The first calculation is based on the amount of MFSP security that the Alberta government has collected based on the amount of approved hectares of each mining project. A deficit to this approach is that hectare projections were obtained via third party sites, which were difficult to obtain, potentially inaccurate, and made cost comparisons difficult. The figures included in the approved mine site analysis include both the open-pit mine as well as the hectares for any on-site bitumen upgraders. The inclusion of facilities such as external processing plants may not necessarily skew the reclamation security calculations because the law is clear that all land, even the land containing buildings, must be reclaimed. The inclusion of the entire mine site, as opposed to the exact surface area that has been mined, results in a strong deflation of the amount of security per hectare.

The second calculation, the amount of MFSP security that the Alberta government has collected based on mined hectares, is based on the amount of hectares that are currently being actively mined or have been mined in the past. Only Shell has publicly released this figure, ${ }^{88}$ and they have decided to divest from the oil sands. ${ }^{89}$ Neither government websites nor nongovernmental organizations track the amount of developed oil sands hectares per mine. Mining companies have refused to disclose this information, citing corporate confidentiality. These factors reflect the transparency difficulties with the amount of information made to the public.

TABLE 2:

2016 RECLAMATION LIABILITY SECURITY BASED ON APPROVED MINE Site

\begin{tabular}{|l|l|c|c|c|c|c|c|}
\hline \multicolumn{1}{|c|}{$\begin{array}{c}\text { EPEA Approval } \\
\text { Holder }\end{array}$} & \multicolumn{1}{|c|}{$\begin{array}{c}\text { Project } \\
\text { Name }\end{array}$} & $\begin{array}{c}\text { EPEA } \\
\text { Approval } \\
\text { Number }\end{array}$ & $\begin{array}{c}\text { Financial } \\
\text { Security } \\
\text { Amount }\end{array}$ & $\begin{array}{c}\text { Hectares } \\
\text { of } \\
\text { Project }\end{array}$ & $\begin{array}{c}\text { Security } \\
\text { per } \\
\text { Hectare }\end{array}$ & $\begin{array}{c}\text { Asset } \\
\text { Safety } \\
\text { Factor }\end{array}$ & $\begin{array}{c}\text { Completed } \\
\text { Reclamation } \\
\text { for 2016 (Ha) }\end{array}$ \\
\hline $\begin{array}{l}\text { Canadian Natural } \\
\text { Resources Limited }\end{array}$ & $\begin{array}{l}\text { Horizon Oil } \\
\text { Sands }\end{array}$ & 149968 & $\$ 61,200,000$ & $28,482^{90}$ & $\$ 2,149$ & 32.4 & 36.32 \\
\hline $\begin{array}{l}\text { Fort Hills Energy } \\
\text { Corporation }\end{array}$ & $\begin{array}{l}\text { Fort Hills Oil } \\
\text { Sands }\end{array}$ & 151469 & $\$ 38,958,605$ & $17,864^{91}$ & $\$ 2,181$ & 9 & 0 \\
\hline $\begin{array}{l}\text { Imperial Oil Resources } \\
\text { Ventures Limited }\end{array}$ & $\begin{array}{l}\text { Kearl Oil } \\
\text { Sands }\end{array}$ & 46586 & $\$ 64,655,000$ & $19,155^{92}$ & $\$ 3,375$ & 8.4 & 4.9 \\
\hline
\end{tabular}

Shell Canada Limited, "Oil Sands Performance Report 2016" (Calgary: Shell Canada, 2017), online: $<$ s04. static-shell.com/content/dam/royaldutchshell/documents/corporate/2016-oil-sands-performancereport-shell-canada-limited-final.pdf $>$ [Shell Report].

$89 \quad$ Katakey \& Jordan, supra note 1.

$90 \quad$ "Horizon Mine,” Oil Sands Magazine (25 July 2018), online: <www.oilsandsmagazine.com/projects/ cnrl-horizon-mine>.

91 "Fort Hills Mine,” Oil Sands Magazine (25 July 2018), online: <www.oilsandsmagazine.com/projects/ suncor-fort-hills-mine>.

92 "Kearl Mine," Oil Sands Magazine (25 July 2018), online: <www.oilsandsmagazine.com/projects/ imperial-oil-kearl-mine>. 


\begin{tabular}{|l|l|c|c|c|c|c|c|}
\hline \multicolumn{1}{|c|}{$\begin{array}{c}\text { EPEA Approval } \\
\text { Holder }\end{array}$} & \multicolumn{1}{|c|}{$\begin{array}{c}\text { Project } \\
\text { Name }\end{array}$} & $\begin{array}{c}\text { EPEA } \\
\text { Approval } \\
\text { Number }\end{array}$ & $\begin{array}{c}\text { Financial } \\
\text { Security } \\
\text { Amount }\end{array}$ & $\begin{array}{c}\text { Hectares } \\
\text { of } \\
\text { Project }\end{array}$ & $\begin{array}{c}\text { Security } \\
\text { per } \\
\text { Hectare }\end{array}$ & $\begin{array}{c}\text { Asset } \\
\text { Safety } \\
\text { Factor }\end{array}$ & $\begin{array}{c}\text { Completed } \\
\text { Reclamation } \\
\text { for 2016 (Ha) }\end{array}$ \\
\hline $\begin{array}{l}\text { Shell Canada Limited } \\
\text { formerly) }\end{array}$ & $\begin{array}{l}\text { Muskeg } \\
\text { River Mine }\end{array}$ & 20809 & $\$ 111,277,442$ & $13,581^{93}$ & $\$ 8,194$ & 19.72 & 188.3 \\
\hline $\begin{array}{l}\text { Shell Canada Limited } \\
\text { formerly) }\end{array}$ & $\begin{array}{l}\text { Jackpine } \\
\text { Mine }\end{array}$ & 153125 & $\$ 72,361,895$ & $7,958^{94}$ & $\$ 9,093$ & 28.87 & 32.9 \\
\hline Suncor Energy Inc. & $\begin{array}{l}\text { Base } \\
\text { Operations }\end{array}$ & 94 & $\$ 359,096,654$ & & & 11 & \\
\hline Syncrude Canada Ltd. & $\begin{array}{l}\text { Mildred } \\
\text { Lake, Aurora } \\
\text { North/South }\end{array}$ & 26 & $\$ 205,303,024$ & $27,861^{95}$ & $\$ 7,369$ & 6.71 & 233.4 \\
\hline $\begin{array}{l}\text { Total E\&P Canada } \\
\text { Ltd. }\end{array}$ & $\begin{array}{l}\text { Joslyn North } \\
\text { Mine }\end{array}$ & 228044 & $\$ 26,400,059$ & $8,600^{96}$ & $\$ 3,070$ & $\mathrm{n} / \mathrm{a}$ & 54.44 \\
\hline & Total & & $\$ \mathbf{9 3 9 , 2 5 2 , 6 7 9}$ & $\mathbf{1 2 3 , 5 0 1}$ & $\$ \mathbf{7 , 6 0 5}$ & & \\
\hline
\end{tabular}

TABLE 3:

2016 RECLAMATION LIABILITY SECURITY BASED ON Mined HeCTARES ${ }^{97}$

\begin{tabular}{|l|l|c|c|c|c|c|c|}
\hline $\begin{array}{l}\text { EPEA Approval } \\
\text { Holder }\end{array}$ & \multicolumn{1}{|c|}{$\begin{array}{c}\text { Project } \\
\text { Name }\end{array}$} & $\begin{array}{c}\text { EPEA } \\
\text { Approval } \\
\text { Number }\end{array}$ & $\begin{array}{c}\text { Financial } \\
\text { Security } \\
\text { Amount }\end{array}$ & $\begin{array}{c}\text { Mined } \\
\text { Hectares }\end{array}$ & $\begin{array}{c}\text { Security } \\
\text { per } \\
\text { Hectare }\end{array}$ & $\begin{array}{c}\text { Asset } \\
\text { Safety } \\
\text { Factor }\end{array}$ & $\begin{array}{c}\text { Completed } \\
\text { Reclamation } \\
\text { for 2016 (Ha) }\end{array}$ \\
\hline $\begin{array}{l}\text { Shell Canada Limited } \\
\text { (formerly) }\end{array}$ & $\begin{array}{l}\text { Muskeg } \\
\text { River Mine }\end{array}$ & 20809 & $\$ 111,277,442$ & 8,633 & $\$ 12,890$ & 1972 & 188.3 \\
\hline $\begin{array}{l}\text { Shell Canada Limited } \\
\text { (formerly) }\end{array}$ & $\begin{array}{l}\text { Jackpine } \\
\text { Mine }\end{array}$ & 153125 & $\$ 72,361,895$ & 5,485 & $\$ 13,192$ & 28.87 & 32.9 \\
\hline
\end{tabular}

Needless to say, based on the figures retrievable in public sources, it appears the government is holding an inadequate amount of reclamation security from EPEA approval holders of each oil sands mine. The amount of security collected per approved mine site ranges from $\$ 2,149$ to $\$ 9,093$ of security per hectare. The amount of security collected per mined hectare (based on the limited sample) ranges from $\$ 12,890$ to $\$ 13,192$ per hectare. For comparison, the MFSP is supposed to be based on reclamation of $\$ 45,000$ to $\$ 75,000$ per hectare. However, it must be noted that the above calculations are likely skewed due to the limited (and potentially inaccurate) public availability of the amount of hectares per project. Government disclosure of per hectare projects and per hectare mined sites would go a long way to assisting monitoring by third parties.

93 "Muskeg River," Oil Sands Magazine (25 July 2018), online: <www.oilsandsmagazine.com/ projects/shell-albian-sands-muskeg-river-mine>.

94 “Jackpine," Oil Sands Magazine (25 July 2018), online: <www.oilsandsmagazine.com/projects/ shellalbian-sands-jackpine-mine $>$.

$95 \quad$ Syncrude, "Land Reclamation" (2012), online: <www.syncrudesustainability.com/2012/environment/ land-reclamation $/>$.

96 Geoffrey Morgan, "Shelved and Supersized: An Oil Sands Paradox as Massive Joslyn Project Expanded," Financial Post (14 October 2014), online: <https://business.financialpost.com/commod ities/energy/shelved-and-supersized-an-oil-sands-paradox-as-massive-joslyn-project-expanded $>$.

$97 \quad$ Shell Report, supra note 88 at 10. 
Several things could account for the incredibly low amount of security. There are numerous investors in the oil sands, not just the EPEA approval holders. It is unclear in the annual MFSP report if the "financial security amount" is based on each mine or each approval holder. Should it be the latter, then why is the security posted for all investors in the oil sands, on a per mine basis, not disclosed? Even with that being said, the highest security per hectare estimate is off from the $\$ 45,000$ standard by a factor of more than 3.4, meaning the amount of security being collected is insufficient.

What is also telling is companies' asset to liability ratios, which the government discloses in its MFSP annual reports. All EPEA approval holders have deemed assets outweighing deemed liabilities by a factor of more than three. Additional security is only needed if this safety factor falls below the 3:1 ratio. However, to the contrary, the high asset to liability ratios indicate these firms are asset heavy, and may be able to bear the cost of additional regulation.

A similar asset to liability ratio is provided by the AER for all oil sands licensees in its monthly Liability Management Programs Results Report. ${ }^{98}$ The LMR calculates all licensees' deemed asset to deemed liability ratios for all of Alberta's Liability Management programs. While the amount of security per licensee could easily be provided in this document to increase public transparency, it is not. Instead, the LMR report only provides the overall amount of security collected.

What is particularly troubling in the 2018 LMR Report is the fact that 43.81 percent of licensees have an asset to liability ratio "below the Industry Threshold" and 77 percent are below a 3:1 LMR range. ${ }^{99}$ According to the report, only 0.0012 percent of all deemed assets are collected in security, which is exceptionally low. ${ }^{100}$

With that being said, there is some evidence that the amount of security is gradually increasing over the years. For example, a Pembina report found that the amount of security collected per hectare has been increasing since $1984 .{ }^{101}$ Furthermore, the new MFSP values the amount of security needed for future work planned but not performed at $\$ 75,000$ per hectare. ${ }^{102}$ This is in line with, or even above, the average cost of reclamation. Even if the level of base security is sufficient to cover the future reclamation cost, the amount of security is based on a very limited view of environmental liabilities and does not include the presentday value of the real risk of asset stranding.

With that being said, there is also evidence that the AER is getting more serious about enforcing its security obligations, keeping in mind the serious political and financial constraints the province is facing. For example, the AER recently shut down the large sour gas operator, Lexin Resources, largely due to its failure to comply with AER orders regarding spills, abandoned wells, administrative fees, and its security deposits for well 2018) at 1 [2018 LMR Report].

Ibid.

Ibid.

Lemphers, Dyer \& Grant, supra note 8 at 21.

AG Report 2015, supra note 23 at 28. 
reclamation. ${ }^{103}$ While this decision sends a signal to other energy operators about the cost of non-compliance, it also leaves the Alberta government in charge of 1,380 well sites, 201 pipeline licenses, and 81 facilities, all of which had insufficiently posted security. ${ }^{104}$

As a final point, there is some evidence that the current ability to reclaim a site is not sufficiently taken into account when granting federal environmental approvals. For example, in Pembina Institute for Appropriate Development v. Canada (Attorney General) the Federal Court allowed for a further 900 hectares of wetland marsh to be developed into an open-pit oil sands mine without any current technology being able to reclaim the land. ${ }^{105}$ Instead, the Court allowed for the project to proceed due to "adaptive management" principles (the principle of allowing large uncertainties in the present to be dispelled based on the notion that future technological development and system monitoring will resolve the uncertainty). ${ }^{106}$ The Court believed that future technologies would eventually advance to the point that the currently substandard mitigation measures could become compliant with environmental legislation in the future. The environmental panel's role was deemed to be "predictive" and the Court thought it would be economically stifling to require future uncertainties to be fully resolved. ${ }^{107}$ From the lens of reclamation security, it is difficult to take security for activities that are currently economically uncertain, if not impossible.

\section{ASSET RETIREMENT OBLIGATIONS}

Canadian accounting standards are another source of parallel regulation. Accountants only account for liabilities when the likelihood of the liability being incurred, as a result of environmental law or company policy, is "reasonably determined." ${ }^{108}$ More specifically, accounting standards require that liabilities be disclosed if they are "material," meaning likely to occur and estimable, ${ }^{109}$ or, if they are not estimable but likely to occur. ${ }^{110}$ Canadian and United States securities law mirror the accounting requirement that material information needs to be disclosed. All risks and uncertainties known to management that would be "reasonably likely to cause actual [financial] results to differ materially from material forward-looking information" are required to be disclosed in the Management Discussion and Analysis (MD\&A) section of a publicly traded company's financial reports. ${ }^{111}$

Reclamation costs are likely to occur because there is a clear statutory obligation to restore the land. Therefore, individual reclamation obligations are likely to be financially material and must be accounted for as per accounting and legal standards. Consequently, the only ambiguity surrounding the disclosure of reclamation liabilities should be centered around whether environmental liabilities that are not clearly incorporated into a statutory definition of reclamation liabilities are a financial liability that is "likely to occur," especially for the

Tracy Johnson, “Alberta Shuts Down Lexin Resources, Leaving Big Mess to Clean Up" CBC News (15 February 2017), online: < www.cbc.ca/news/canada/calgary/lexin-resources-shut-down-1.3984287>.

Ibid.

2008 FC 302 at paras 59-62.

Ibid at para 60 .

Ibid at para 61.

Canadian Institute of Chartered Accountants, CICA Handbook (Ottawa: CICA, 2016), s 3290.12

[Accounting Handbook].

Ibid.

Ibid, s 3290.15 .

Continuous Disclosure Obligations, OSC NI 51-102 (2018), s 5.8(2). 
environmental liabilities that involve non-estimable future costs. As theorized by corporate disclosure theory, there is a chance that many of these liabilities are not being recognized as "likely to occur" in financial statements because they are not expressly listed under the regulation and fall below the partial disclosure equilibrium. ${ }^{112}$ If the government wants to hold companies accountable for their broader reclamation liabilities, it must enhance the transparency of the AER program or set clear legislative and accounting guidelines on what constitutes true "reclamation."

Oil sands operators have an accounting equivalent to reclamation liabilities: asset retirement obligations (AROs). AROs are defined as the estimated cost of activities that a firm is legally required to complete to retire its tangible long-lived assets as a result of existing or enacted law, statute, ordinance, written or oral contracts, or by promissory estoppel. ${ }^{113}$ Five out of sixteen companies involved in active oil sands mines are publicly traded. ${ }^{114}$ This means that their AROs are publicly disclosed on the company's financial statement. An ARO informs investors and the public about how a company is accounting for future risks and offers assurances that risks are properly being accounted for. ${ }^{115}$ Importantly, AROs do not set any money aside as it is merely a disclosure obligation. ${ }^{116}$

Interestingly, the amount a company discloses in its ARO is not linked to its security assessment under the MFSP. For example, a study done in 2012 indicated that corporate disclosures by Canadian Oil Sands Ltd. placed expected reclamation costs in its ARO at $\$ 180,000 /$ hectare, despite high-end estimates in the MFSP being $\$ 75,000 /$ hectare. ${ }^{117}$ In 2008 , Suncor listed its ARO estimate at $\$ 3.5$ billion yet only had $\$ 271$ million held for reclamation security under the former regime, which was supposed to collect security based on an operator's full liability one year in the future. ${ }^{118}$ While security is a portion of full reclamation liabilities, this figure still indicates that there is a stark difference between AROs and a company's estimated reclamation liabilities under the government's security program.

Unlike MFSP calculations, companies must disclose the methodology used to calculate AROs as per International Accounting Standard 37. ${ }^{119}$ A disclosure of methodology does not mean that the aggregate ARO is broken down on a per mine basis. ${ }^{120}$ Methodology simply means the factors that were analyzed to arrive at the aggregate number. This disclosure occurs without requiring a company to reveal its confidential technical base. While a full breakdown of methodology would be preferable to evaluate the sufficiency of reclamation liabilities under the MFSP, the AROs present a better alternative than the current MFSP policy of only providing the overall amount of security held and an asset to liability ratio per company.

For more discussion on this concept, see Li \& McConomy, supra note 59 at 280.

Accounting Handbook, supra note 108, s 3110; HTK Consulting, "Asset Retirement Obligations: ASPE 3100 " (2016), online: <htkconsulting.com/HTKNotes/PMR/ASSET\%20RETIREMENT\%20OBLIG ATIONS\%20-\%20ASPE.pdf> [PMR Note].

Lemphers, Dyer \& Grant, supra note 8 at 27.

Ibid at 28 .

Ibid at 29 .

Thorley, supra note 25.

Lemphers, Dyer \& Grant, supra note 8 at 29.

International Accounting Standards Board, IAS 37 - Provisions, Contingent Liabilities and Contingent Assets (London, UK: IASB, 2005).

Lemphers, Dyer \& Grant, supra note 8 at 31. 
While the MFSP can benefit from ARO guidelines, they are not comprehensive and are not the perfect solution. Companies can choose not to include many environmental liabilities under their ARO. For example, AROs currently exclude tailing lakes, assets of an indefinite life, and reclamation activities if the fair value cannot be determined. ${ }^{121}$ The ARO definition of a "liability" can be restrictive: i) "they embody a duty to others that entails yielding of economic benefits," ii) there is "little or no discretion to avoid it," and iii) the "event obligating the entity has already occurred." 122 Therefore, technically AROs measure a mine's full reclamation obligation based on the level of development that has already occurred. Companies have discretion whether to incorporate planned development into their ARO figure. Furthermore, new legislation is only taken into account under AROs if it is "virtually certain to be enacted." 123

Curiously, accounting professionals may already be broadening the notion of AROs. For instance, KPMG states: “[a]lthough the Statement [143, referring to items included in AROs] applies to legal obligations to retire an asset, we believe that the Statement also applies to legal obligations related to the retirement of assets even when the enterprise is not legally required to retire an asset." ${ }^{\text {"24 }}$ Although accounting Statement 143 limits AROs to the "retirement of a tangible long-lived asset that results from the acquisition, construction, development or the normal use of the long-lived asset," 125 there is nothing preventing accountants from recognizing end of life activities that go beyond the basic legal requirements (known as "constructive obligations").

Further research should be conducted into whether there are large discrepancies between current AROs and the amount stated in a company's MFSP report. However, this analysis is critically hindered by the fact that the MSFP reports only disclose the total amount of security placed under the program, not a mine operator's stated amount of total reclamation costs. Underreporting reclamation liabilities in an ARO can exaggerate a company's true profits because major liabilities have been excluded. Should there continue to be a large discrepancy between the ARO and MFSP assessments, this shows that either (1) the legislature is allowing companies to understate their reclamation liabilities under the MFSP or (2) the company is purposely understating their future reclamation costs to avoid putting up more security. Consistent and heavy auditing, with a consideration of a company's ARO, reduces the risk of any misstatements or undervaluations of reclamation liabilities.

One of the best solutions would be to force companies to place the ARO prominently on its balance sheet on a per mine basis, have MFSP reclamation security amounts be based on a company's ARO calculation (with verification), and have the methodology breakdown per mine be available in the online MFSP annual report. Six benefits would result from simultaneously strengthening both the MFSP and ARO regimes: (1) it would incentivize early and staged reclamation in order to reduce listed liabilities to make the company more attractive to investors; (2) managers would consciously assess what types of activities they

KPMG Department of Professional Practice, Guide to Accounting for Asset Retirement Obligations: An Analysis of FASB Statement No.143, ed by Lee Dombrowski (New York: KPMG LLP, 2003) at 3. Ibid.
} 
are undertaking and the resultant reclamation obligations; (3) extractive activities that would result in higher reclamation liabilities (such as open-pit oil sands mining versus in-situ extraction) would be priced higher on the market; (4) companies would be encouraged through shareholder pressure to place adequate security to address these tangible, certain, future costs; (5) it allows for experts and shareholders to assess the sufficiency of a company's risk assessments; and (6) it would increase public trust that a company has taken their legal reclamation obligations seriously.

If a mine operator's MFSP total reclamation liability was made public, it could be assessed against the corporation's ARO disclosure (which is made public for public corporations). As mentioned above, AROs are based on materiality and reclamation liabilities are material. Should there be a large discrepancy between the MFSP and ARO figures, companies who severely deflate their reclamation liability estimates in an effort to post less financial assurance could potentially be prosecuted for a material misstatement or omission under corporate or securities law.

While accounting regulations can be effective, they are more costly than requiring public disclosure of cost assessments. This is because disseminating public records has a lower marginal cost and strict accounting standards are costly to enforce, especially when the liabilities have an inherent uncertainty. ${ }^{126}$

\section{The Definition of ReClamation Does Not ACCOUNT FOR BROADER ENVIRONMENTAL LIABILITIES}

The legislative guidelines on what environmental liabilities are included in "reclamation" become important because it is highly likely that the industry will only reclaim the land to the extent of their legal obligation. Furthermore, the extent of the reclamation obligation is what the AER uses to determine its asset to liability ratios upon which the level of reclamation security is based. ${ }^{127}$ The broader term "environmental liability" means the "costs associated with the environmental impacts throughout the life of the mine." ${ }^{\prime 28}$ Despite many environmental liabilities being a part of restoring the land, several are unlikely to be incorporated into the AER's determination of reclamation liabilities. For example, the statutory definition is unlikely to cover reclaiming initial land disturbance and seismic lines, test pits and road works, the costs of damage to airsheds, groundwater disruption and contamination, greenhouse gas emissions, plant-site contamination, peatlands (bogs and ferns), end-pit lakes (with and without tailings), dedicated storage areas for dry tailings, overburden dumps, and processing plants and post-reclamation maintenance. ${ }^{129}$ Reclamation for test holes and some mine site and processing plants are explicitly excluded from MFSP reclamation definitions. ${ }^{130}$ Because none of these environmental liabilities are likely to be included in reclamation liabilities, they are not shown on an operator's overall reclamation balance sheet despite being a consequence of their mining activity.

\footnotetext{
126 Yue Li, Gordon D Richardson \& Daniel B Thornton, "Corporate Disclosure of Environmental Liability Information: Theory and Evidence" (1997) 14:3 Contemporary Accounting Research 435 at 447. Directive 006, supra note 49 at 20. Lemphers, Dyer \& Grant, supra note 8 at 11. Ibid at 8, 11 . Directive 006, supra note 49 at 8.
} 
Part of the reason many environmental liabilities are not properly accounted for stems from the vague language in the legislation. The government regulation only requires operators to reclaim the land to an "equivalent land capability," 131 meaning that "the ability of the land to support various land uses after conservation and reclamation is similar to the ability that existed prior to an activity being conducted on the land, but that the individual land uses will not necessarily be identical." ${ }^{132}$ While this definition gives the AER flexibility in determining the scope of reclamation liabilities, it also allows the industry to understate the true environmental impact of oil sand activities that it should be accountable for. Clear legislative definitions are essential because legislation lays out the scope of what is deemed to be included in reclamation costs. Corporations will only account for liabilities when the likelihood of the liability being incurred is reasonably determinable. ${ }^{133}$ If corporations do not believe that environmental liabilities such as fossil fuel emissions and damages to airsheds will be included in the cost of restoration and reclamation, the security for these costs will never be accounted for under the MFSP.

\section{STRANDing OF ASSETS}

Canada has recently committed itself to keeping the increase in global average temperature below $2{ }^{\circ} \mathrm{C}$. ${ }^{134}$ In order to do so, global emissions from fossil fuels need to radically decrease while governments, including Canada, pursue ambitious environmental targets. One thing is for certain: in order to avoid a $2^{\circ} \mathrm{C}$ increase in global average temperature, a significant portion of discovered fossil fuels need to be left in the ground. Based on International Energy Agency assessments, oil and coal demands need to peak before 2020 and then decline in order for the $2{ }^{\circ} \mathrm{C}$ target to be reached. ${ }^{135}$ Some sources even speculate that as much as 80 percent of known reserves need to be left unextracted. ${ }^{136}$ Fossil fuel corporations' balance sheets show a different view - no firm has yet to factor in "unburnable carbon" into its reserve, despite proven international reserves containing almost three times the $2{ }^{\circ} \mathrm{C}$ carbon budget. ${ }^{137}$ Quite the opposite; in 2012, the 200 largest oil, gas, and coal companies spent $\$ 674$ billion developing new reserves, almost five times the amount they returned to shareholders. ${ }^{138}$ Therefore, these companies are valuing their assets as if government regulation will be ineffective, disregarding the $2^{\circ} \mathrm{C}$ carbon budget, or placing trillion dollar risk allocations on technological developments such as carbon capture and storage. Most investors appear to be of the same mindset, seeing ever-increasing proven reserves as an indicator of future revenues. As shown from the 2008 subprime mortgage

131 CRR, supra note $15, \mathrm{~s} 2$.

132 Ibid, s $1(\mathrm{e})$.

133 Li \& McConomy, supra note 59 at 281.

134 Paris Agreement, being an Annex to the Report of the Conference of the Parties on its twenty-first session, held in Paris from 30 November to 13 December 2015 - Addendum Part two: Action taken by the Conference of the Parties at its twenty-first session, 29 January 2016, Dec 1/CP.21, CP, 21st Sess, UN Doc FCCC/CP/2015/10/Add.1, online: <https://unfecc.int/resource/docs/2015/cop21/eng/ 10a01.pdf>.

135 Nick Robins, HSBC Climate Change Centre of Excellence, "Integrating Environmental Risks into Asset Valuations: The Potential for Stranded Assets and the Implications for Long-Term Investors" (Winnipeg: International Institute for Sustainable Development, 2014) at 3.

136 Bill McKibben, "Why We Need to Keep 80\% of Fossil Fuels in the Ground" (16 February 2016) 350 (blog), online: <https://350.org/why-we-need-to-keep-80-percent-of-fossil-fuels-in-the-ground/>.

137 "Energy Firms and Climate Change: Unburnable Fuel," The Economist (4 May 2013), online: $<$ https:// www.economist.com/news/business/21577097-either-governments-are-not-serious-about-climatechange-or-fossil-fuel-firms-are $>$.

138 Ibid. The 200 largest fossil fuel producers only returned \$126 billion to shareholders in 2012. 
crisis, markets can severely misprice certain risks. HSBC has estimated that there could be a 40 to 60 percent risk to market cap that is not being accounted for. ${ }^{139}$

There is a small but significant risk that oil sands assets may become "stranded" (meaning, they will suffer from unanticipated or premature write offs, downward revaluations, or will be converted to liabilities). ${ }^{140}$ As assets become stranded, threatening the profitability of some fossil fuel producers or mine sites, the ability of the government to have sufficient security to clean up the land for defaulting producers is essential. Moreover, it is important to note that these fossil fuel assets are the same from which financial assurance for reclamation liabilities is derived.

Asset stranding can occur through indirect mechanisms such as divestment campaigns by socially motivated private wealth owners, and other individuals and groups, such as university endowments or public pension funds. ${ }^{141}$ Socially motivated divestment should not be confused with liquidating investments due to other factors, such as a company's poor financial performance. These divestment campaigns aim to encourage direct mechanisms limiting the use of fossil fuel assets — such as pressuring companies to drastically reduce their carbon emissions via "transformative change" and pressuring fossil fuel companies and governments to leave some portion of fossil fuels unburned through legislation, bans on further drilling, or a carbon tax. Fossil fuel assets may also be at risk for disinvestment, which is a distinct process of eliminating individuals' or corporations' ownership of physical assets, for example through legislation requiring forced sales.

The concept of "unburnable carbon" has been around for almost ten years. In 2009, two papers in the scientific journal Nature published finite carbon budgets lower than provable reserves as part of a calculation in order to avoid $2{ }^{\circ} \mathrm{C}$ global warming. ${ }^{142}$ The article by Meinshausen and co-authors, which advocated for unburnable fossil fuels, is one of the most cited environmental studies. ${ }^{143}$

A study by Griffin and co-authors, studied the effect of the publication of the Nature articles on the stock market. ${ }^{144}$ Controlling for other variables, they measured a 1.5 to 2 percent decrease in fossil fuel stock prices within three days of the Nature articles' publication. ${ }^{145}$ Interestingly, the observed drop due to the Meinshausen and co-authors' article was greater than a later publicized news story about carbon taxes. ${ }^{146}$ While there was a significant initial drop in 2009, subsequent unburnable carbon stories in years such as 2012

Paul Spedding, Kirtan Mehta \& Nick Robins, "Oil \& Carbon Revisited: Value at Risk From 'Unburnable' Reserves” (London: HSBC Global Research, 2013) at 1, online: Social Science Research Network $<$ https://papers.ssrn.com/sol3/papers.cfm?abstract id=2220738>.

Atif Ansar, Ben Caldecott \& James Tilbury, Stranded Assets Programme,"Stranded Assets and the Fossil Fuel Divestment Campaign: What Does Divestment Mean for the Valuation of Fossil Fuel Assets?" (Oxford: University of Oxford's Smith School of Enterprise and the Environment, 2013) at 2 [Stranded Assets Programme]; Robins, supra note 135 at 3.

For more information on fossil fuel asset stranding via divestment see Stranded Assets Programme, ibid. Myles R Allen et al, "Warming Caused by Cumulative Carbon Emissions Towards the Trillionth Tonne" (2009) 458 Nature 1163; Malte Meinshausen et al, "Greenhouse-Gas Emission Targets for Limiting Global Warming to $2^{\circ} \mathrm{C}$ " (2009) 458 Nature 1158 .

Paul A Griffin et al, "Science and the Stock Market: Investors' Recognition of Unburnable Carbon" (2015) 52 Energy Economics 1 at 1.

Ibid.

Ibid at 3.

Ibid. 
and 2013 have had an imperceptible impact. ${ }^{147}$ This may suggest that some investors have already deemed the risk of asset stranding to be minimal and that subsequent articles have released little new risk information to investors. Several economists use a "hyperbolic discounting model" in assigning firm valuations which values immediate rewards higher than distant future risks. ${ }^{148}$

Growing fossil fuel divestment campaigns also present a risk to the viability of oil sands and the assets upon which their reclamation security are based. Atif Ansar, Ben Caldecott, and James Tilbury completed an assessment of the fossil fuel divestment campaign in 2013, which was launched in 2011 by Swarthmore College and reaffirmed by 350 in 2012. ${ }^{149}$ Looking at previous divestment campaigns (such as tobacco and South Africa), they found that there are three "waves" of divestment in any campaign. The first stage consists of smallscale divestment by religious groups and industry-related public organizations. The second stage involves divestment by universities, cities, and select public institutions. The third stage involves divestment by the wider public market. ${ }^{150}$ It is not until the third stage when very large pension funds become involved and market norms change. According to the authors, the fossil fuel divestment campaign was in the second wave of divestment in 2013. ${ }^{151}$ As there has yet to be a large scale, worldwide, divestment of fossil fuel securities, it appears the divestment campaign has stalled at the second stage.

Despite the plausible upper limit for oil and gas equity divestment by university endowments and public pension funds being between $\$ 240-\$ 600$ billion (with approximately another \$120-\$300 billion for debt), the direct impacts of fossil fuel divestment on equity or debt are likely to be marginal (as oil and gas fossil fuel companies have an approximate market cap of $\$ 4$ trillion, with coal companies having a market cap less than $\$ 60$ billion). ${ }^{152}$ As these endowments and funds represent only a small pool of funds available to fossil fuel companies, internationally, fossil fuel share prices as a whole are unlikely to be significantly impacted in the short term. ${ }^{153}$ Moreover, the effects of socially motivated divestment are likely to be tempered by neutral investors who would purchase the divested holdings, especially if the stocks faced a short-term discount. ${ }^{154}$ Withdrawal of debt finance by some banks is unlikely to pose a serious issue to a fossil fuel company's debt financing (through either their short-term liquidity or Capex). ${ }^{155}$

The largest threat that divestment campaigns pose to oil sands giants is a change in market norms, but even market norms are unlikely to yield a substantial direct effect to fossil fuel producer's equity, and only a minor effect on debt financing. ${ }^{156}$ However, if a campaign is successful in closing off a channel of money that was previously available, then the firm's stock price may face downward pressure. Small scale divestment by a few powerful lead

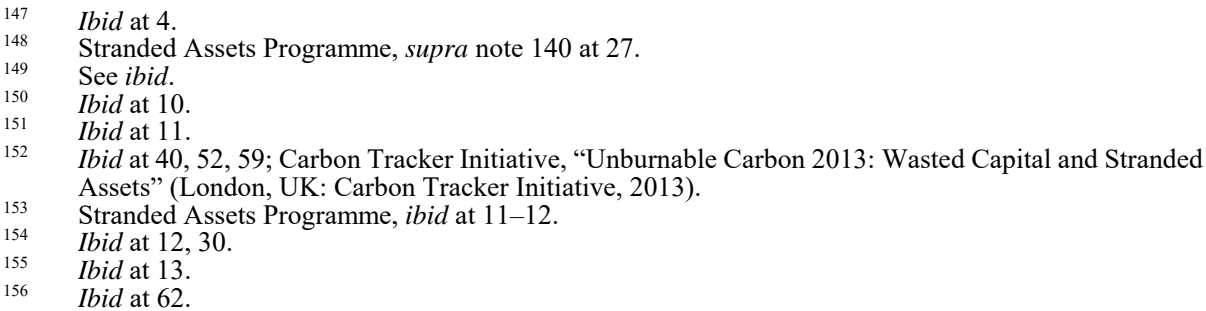


investors can lead to a tipping point of large scale divestment. Moreover, if the stigmatization of divestment is successful in causing neutral debt or equity investors to lower a firm's subjective probability of meeting net cash flows, a company's valuation can become permanently depressed. This lowering of price would be of a greater magnitude than any direct divestment and presents a significant risk for fossil fuel companies. ${ }^{157}$

The stigmatization of targeted large-scale divestment can have secondary impacts that may also depress a company's valuation. As public concerns about climate change increase, so too does the risk of stigmatization of fossil fuel industries, even if the companies are abiding by high business ethics. For instance, suppliers, subcontractors, and potential employees can become weary of working for a stigmatized company. ${ }^{158}$ Moreover, governments and politicians may disassociate themselves from stigmatized firms that would jeopardize their re-election chances and potentially bar the companies from competing for public tenders or gaining property or leasing rights. ${ }^{159}$ Most importantly, stigmatization can permanently compress trading multiples of public companies and the share price to earnings $(\mathrm{P} / \mathrm{E})$ ratio. ${ }^{160}$ For instance, the Russian company Rosneft ( $\$ 88$ billion valuation in 2013) produces more barrels of oil than ExxonMobil ( $\$ 407$ billion valuation in 2013) but investors assign a lower probability to Rosneft being able to convert its reserves into positive cash flows due to weak corporate governance. ${ }^{161}$ However, stigma can and will be diluted by fossil fuel companies, with the industry likely scapegoating coal companies (due to that industry's high emissions output, small fraction of market, and illiquidity of stock) or companies that are willfully negligent. ${ }^{162}$

Canada is a particularly high target for environmental legislation and divestment campaigns due to the fact that it is a developed country and the seventh largest producer of the world's oil supply. ${ }^{163}$ Some Canadian universities, like Laval, have committed to divesting from fossil fuel stocks, whereas other universities, like the University of Ottawa and the University of British Columbia, have rejected divestment, preferring instead to increase investment in renewable energy. ${ }^{164}$ Almost every prior divestment campaign has been successful in forcing restrictive legislation. ${ }^{165}$

If stigmatization were to increase oil and gas companies' discount rate, technically or politically difficult projections may be shelved. ${ }^{166}$ Oil sands extraction is known to be a higher carbon-intensive process than conventional sources of crude oil and natural gas ${ }^{167}$ and

Ibid at 13, 31, 33, 65 .

Ibid at 14, 65 .

Ibid.

Ibid at 14

Ibid at 14, 68 .

Ibid at 15,69 .

United States Energy Information Administration, "International Energy Statistics: Production of Crude Oil Including Lease Condensate" (2016), online: $<$ https://www.eia.gov/beta/international/data/browser/ $\# /$ ?pa $=00000000000000000000000000000000002 \& \mathrm{c}=4100000002000060000000000000 \mathrm{~g} 00020000$ $0000000000001 \& \mathrm{tl} \mathrm{id}=5-\mathrm{A} \& \mathrm{vs}=\mathrm{INTL} .57-1-\mathrm{AFRC}-\mathrm{TBPD} . A \& \mathrm{vo}=0 \& \mathrm{v}=\mathrm{H} \& \mathrm{end}=2017 \backslash>$.

Farnia Fekri, "The Fossil Fuel Divestment Movement Has Come to Canadian Universities" Motherboard (21 February 2017), online:<https://motherboard.vice.com/en_us/article/qkxvab/fossil-fuel-divestmentlaval-university-canada>.

Stranded Assets Programme, supra note 140 at 14.

Ibid at 33.

Alex D Charpentier, Joule A Bergerson \& Heather L MacLean, "Understanding the Canadian Oil Sands Industry’s Greenhouse Gas Emissions" (2009) 4:1 Environmental Research Letters 1. 
it is one of the most expensive methods of oil production. The Canadian political environment, through both rhetoric and international treaties, has asserted that it wishes to limit greenhouse gas emissions. Alberta is a particularly high target as it makes up 38 percent of Canada's emissions. ${ }^{168}$ Moreover, many economists and environmentalist have suggested that oil sands should be the first oil and gas fossil fuel source to be abandoned. ${ }^{169}$ The per barrel extraction costs, technical difficulty of extracting oil sands, and difficult political environment places oil sands extraction at a heightened risk to asset stranding compared to other oil and gas sources.

The oil sands industry has already shown that it is particularly susceptible to shocks in world oil prices, which raises questions about whether it can stand the shocks of increasing use of renewable energies, prohibitive legislation, or the more general risks of asset stranding through strategies like divestment campaigns. According to the Canadian Association of Petroleum Producers, capital spending in Canada's oil and natural gas sector has declined $\$ 50$ billion, or 62 percent in the past two years. ${ }^{170}$

It also appears that international securities regulators and auditing companies are looking into fossil fuel companies' failure to price the risk of asset stranding, particularly those with large holdings in the oil sands. Since 2007, Exxon mobil has nearly quadrupled its oil sands reserves, from 1.4 to 5.1 billion barrels. ${ }^{171}$ The company had previously been subject to an attack by environmental activist shareholders in 2014, which resulted in the company releasing an essentially dismissive report which predicted that oil and gas will remain the dominant source of energy through $2040 .{ }^{172}$ On the first page, the report clearly states that, "we are confident that none of our hydrocarbon reserves are now or will become "stranded." "173 Yet in 2016, the United States Securities and Exchange Commission (SEC) launched a probe against Exxon for failing to account for falling crude oil prices, and failing to account for limited fossil fuel use due to climate change. ${ }^{174}$ Because the oil sands process is expensive, large scale oil sands extraction is dependent on a very high price of oil. The SEC considered whether Exxon's continued statements that its oil sands reserves were safe despite falling world petroleum prices was a material misstatement to investors due to an overstatement of the viability of developing its reserves.

Environment and Climate Change Canada, "Canadian Environmental Sustainability Indicators: Greenhouse Gas Emissions" (Gatineau: Environment and Climate Change Canada, 2017) at 12.

Christophe McGlade \& Paul Ekins, "The Geographical Distribution of Fossil Fuels Unused When Limiting Global Warming to $2^{\circ} \mathrm{C} "$ (2015) 517 Nature 187.

Canadian Association of Petroleum Producers, "Capital Investment in Canada's Oil and Gas Industry Down 62\% in 2 Years," Oil \& Gas Product News (7 April 2016), online: <https://www.oilandgas productnews.com/article/23138/capital-investment-in-canadas-oil-and-gas-industry-down-62-in-2years $>$.

Nicholas Kusnetz, "Exxon's Big Bet on Oil Sands a Heavy Weight to Carry,” Inside Climate News (30 September 2016), online: $<$ https://insideclimatenews.org/news/29092016/exxon-mobil-change-changeinvestigation-oil-sands-tar-sands-alberta-canada-sec $>$.

Exxon Mobil, News Release, "Energy and Carbon - Managing the Risks" (2014), online: $<\mathrm{https} / / \mathrm{cdn}$. exxonmobil.com/ /media/global/files/energy-and-environment/report---energy-and-carbon---managingthe-risks.pdf $>$.

Ibid at 1.

Bradley Olson \& Aruna Viswanatha, "SEC Probes Exxon Over Accounting for Climate Change," The Wall Street Journal (20 September 2016), online: <https://www.wsj.com/articles/sec-investigatingexxon-on-valuing-of-assets-accounting-practices-1474393593>. 
With that being said, full scale and complete stranding of all oil and gas assets is unlikely to occur. Several companies are not publicly listed on stock exchanges and are closely tied to powerful governments (for instance, Saudi Aramco or the National Iranian Oil Company, some of the largest oil companies in the world). State-owned companies are making up an increasing percentage of total energy output ${ }^{175}$ and therefore the responsibility to limit world emissions lies heavily on countries, not public companies. These countries are unlikely to voluntarily strand the asset that is the main source of their wealth and power.

It is important to note that the fossil fuel divestment campaign substantially differs from all previous divestment campaigns due to its much larger number of firms and market capitalization. Other divestment campaigns such as tobacco, whose companies also had a large market capitalization, failed to choke off the industry's net cash flow, especially due to its recent expansion into smokeless electric cigarettes. ${ }^{176}$ Despite cigarettes being clearly linked to killing off humans, they remain legal, albeit highly regulated. Moreover, as seen during past prohibitions, such as the alcohol prohibition in the United States during the 1920 s, illegal markets quickly open up under outright bans.

There are additional reasons why investors are giving minimal regard to the risk of asset stranding. As previously mentioned, fossil fuel companies are placing a large amount of optimism on carbon capture and storage technologies. ${ }^{177}$ Governments, who would not want to see their large reserves end up stranded, are likely to contribute substantial subsidies to the industry to implement these technologies. For example, the Canadian government has covered 60 percent of the $\$ 1.35$ billion cost for Shell Canada, Chevron Canada, and Marathon Oil to implement a joint carbon capture project in the oil sands. ${ }^{178}$

Further, it is uncertain whether governments will respond to environmental objectives with incentives for cleaner production (for example, subsidies), tax costs (for example, carbon taxes), or both. Future legislation is uncertain and investors are highly reluctant to significantly adjust their portfolios based on risks that may occur 20 to 30 years in the future as the uncertainty of future markets is extraordinarily difficult to calculate and the present value of those risks is adjusted close to zero. Further, almost every agency predicts that there will be an increase in oil demand in the future, despite the need to limit emissions. ${ }^{179}$ However, 2017 was the first year that global investment in electricity surpassed oil and gas, and electricity demand is expected to exponentially grow. ${ }^{180}$ Carbon reduction or stranding is more likely to occur in scapegoated industries such as coal.

As previously mentioned, the dearth of disclosure in a company's financial statements and potential media bias could also be skewing investors' risk assessments. ${ }^{181}$ A recent study has shown that none of the world's largest public fossil fuel producers mentioned "unburnable

\footnotetext{
175 The Economist, supra note 137.

176 Stranded Assets Programme, supra note 140 at 68.

177 See Griffin et al, supra note 143 at 10.

178 Ibid.

179 For instance, see International Energy Agency, World Energy Outlook 2017 (Paris: IEA, 2017) at 2.

$180 \quad$ Ibid at 3

181 Griffin et al, supra note 143 at 10.
} 
carbon" or an equivalent phrase in their $10-\mathrm{K}$ filings ${ }^{182}$ (a securities filing that provides more detail than an annual report).

Instead of an outright limit on unburnable carbon, a carbon tax is the more likely regulatory option in developed countries. If stigmatization can lead to a carbon tax, a company's predicted future cash flow will be impacted (due to reduced demand).

Despite costly environmental policies on the horizon (such as a carbon tax or emission quotas) and large fluctuations in international oil prices, the MFSP intentionally uses an asset-to-liability approach that does not quickly account for sudden, large declines in the price of oil. While this approach provides some stability to a currently rapidly fluctuating market, an abrupt decline in the value of the company's assets would leave an even larger deficit in the security program. ${ }^{183}$

This issue is further compounded by the type of security used for reclamation liabilities. While government legislation allows for security like cash and government bonds, ${ }^{184}$ security for oil sands is typically provided in renewable, irrevocable letters of credit. ${ }^{185}$ Other allowable security instruments are cheques, similar negotiable instruments payable to the Minister of Finance, debentures, term deposits, certificates of deposit, trust certificates, investment certificates assigned to the Minister of Finance, irrevocable letters of guarantee, performance bonds, surety bonds, qualified environmental trusts, and any other security form acceptable to the Director. ${ }^{186}$ A letter of credit is a letter from a bank that guarantees available funds for payments for a limited period of time based on the account holder's existing line of credit. In a letter of credit transaction, the monetary value of the letter is not released by the bank until the party with the held security attempts to redeem the debt. Because a letter of credit is based upon existing assets, a large drop in the price of oil due to environmental legislation may challenge the financial assurance of the letters of credit. However, fossil fuel companies have some of the largest asset reserves and their solvency would not be threatened by minor legislation. Moreover, there is some evidence that a withdrawal of debt finance or an increase in the discount rate is unlikely to pose serious debt financing problems for fossil fuel companies in the short term. ${ }^{187}$

With that being said, recovery from letters of credit can become a large issue if Canadian or international climate change legislation deemed a significant portion of all oil assets to be unextractable. This would result in the collapse of the fossil fuel industry in Canada, but not necessarily abroad. The Alberta government would be left with no tangible assets to reclaim the land because no actual transfer of cash has occurred in the past. Instead, the Alberta government would be left with an abandoned mine, worthless oil assets that would now become a liability, and large reclamation costs. Considering that the province's economy is so dependent on the fossil fuel industry, priorities other than reclaiming the land would likely be placed higher due to staggering budget deficits.

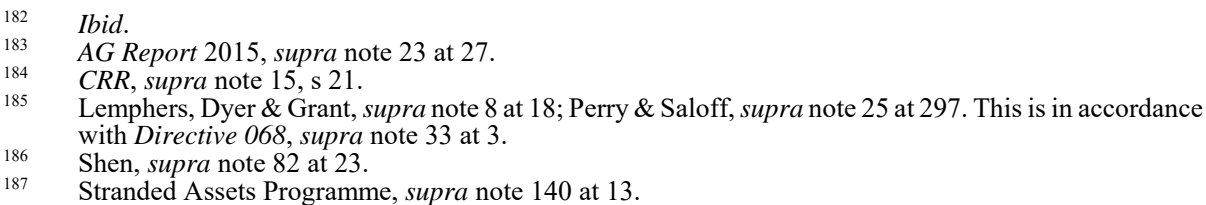


Financial security for reclamation liabilities is often held through a "surety," meaning a party that agrees to hold themselves financially liable for the failures of third parties. Typical sureties for most reclamation liabilities are bonding companies, insurance companies, banks, or other financial institutions. These surety requirements are relatively the same internationally. ${ }^{188}$ Both the Financial Stability Board of the G20 and the Bank of Canada have assessed climate change as presenting a significant risk for financial sector stability, both due to physical risks such as increasingly severe extreme weather events as well as asset stranding. ${ }^{189}$ Banks are less exposed to risk compared to insurance companies, since a bank's assets are shorter term in nature and their investment portfolios are more diversified. ${ }^{190}$ Canada is a resource-based economy. Approximately 20 percent total market capitalization of the Toronto Stock Exchange (TSX) is based in the oil and gas sector, with even larger amounts of indirect investments of fossil fuels through passive index investing. ${ }^{191}$ While large scale asset stranding is unlikely to threaten major Canadian banks' ability to post financial security on behalf of oil sands operators, any sudden province-wide default on this security by multiple oil sands operators at once is likely to have significant consequences for Canada's financial sector as a whole. Stress testing portfolios and having financial security mechanisms that adequately account for risk (such as within the MFSP) are ways to mitigate some large scale distortions.

A more secure configuration for reclamation security was available to the previous Energy Resources Conservation Board. The previous Board could require operators to

post performance bonds, make security deposits, establish internal or external accounts in which funds from revenue are deposited on an ongoing basis for reclamation, abandonment, and decommissioning, and obtain both third-party and environmental damage insurance coverage. ${ }^{192}$

However, this authority was never used. ${ }^{193}$ The AER has the same authority should they wish to address the issues in security collection.

The deemed assets for the asset to liability ratios for overall security are based on current oil and gas production and an annual adjuster that accounts for the international price of oil. If climate change legislation were to deem that a certain amount of oil must not be extracted, the deemed assets would directly fall based on the percentage of prohibited extraction, if not more. Due to the Asset Safety Factor Deposit, evaluated once a year, the operator would

See Shen, supra note 82 at $1-2$.

Timothy Lane, "Thermometer Rising-Climate Change and Canada's Economic Future" (Speech delivered on behalf of the Bank of Canada at the Finance and Sustainability Initiative, Montreal, Quebec, 2 March 2017), online: <https://www.bankofcanada.ca/wp-content/uploads/2017/03/remarks-020 317.pdf $>$; Olaf Weber \& Olena Kholodova, "Climate Change and the Canadian Financial Sector," CIGI Papers No 134 (Waterloo: Centre for International Governance Innovation, 2017) at 1.

Weber \& Kholodova, ibid.

Ibid at 6.

This decision has been now adopted by the AER: True North Energy Corporation Application to Construct and Operate an Oil Sands Mine and Cogeneration Plant in the Fort McMurray Area (22 October 2002), Addendum to Decision 2002-089 at 1, online: <https://www.aer.ca/documents/ decisions/2002/2002-089.pdf> [True North]. Lemphers, Dyer \& Grant, supra note 8 at 19. 
need to post additional security if the asset to liability ratio fell below $3: 1{ }^{194}$ The amount of security needed would be the amount to restore the $3: 1$ ratio. ${ }^{195}$

Moreover, further additional security from the base begins to be collected when the mine has 15 years of reserves left, with the rate of security escalating so that full security is collected when the mine has only six years of reserves left. ${ }^{196}$ The lifespan of a mine is determined via the proven size of its reserves that could be extracted based on current technology. Climate change legislation could change the amount of reserves that could be extracted. The AER should assess whether stranding should be factored into determinations of the lifespan of a mine.

Lastly, there is a logical paradox that stems from using the assets that first created the reclamation liabilities as security for it. In order to pay for the reclamation liabilities of an insolvent mine, the Government of Alberta would have to further develop the mine and incur further reclamation liabilities to recoup the cost from the previous owner. ${ }^{197}$ The AER should investigate if there are any alternatives to using oil assets as security for post-production costs.

Investors do not like uncertainty. Investors face non-trivial costs in accessing information and even once they have acquired the information, they have computational limitations and systematic biases that prevent them from fully analyzing the information. The fossil fuel divestment campaign, with possible asset stranding, will inevitably make the future operating and legislative environment of oil sands operators more difficult. Strengthening the financial assurance program for reclamation liabilities reduces the risk borne by investors and shareholders if a mine suddenly defaults, leaving large liabilities behind. Moreover, increasing financial assurance for reclamation liabilities is the best and clearest path the government can take to safeguard against the risk of asset stranding and to recoup the costs of cleaning up abandoned mine sites that face a sudden default.

\section{CONCLUSION}

Overall, this article concludes that while the MFSP has improved some aspects of the oil sands reclamation security regime, Alberta's MFSP still suffers from some issues of transparency, collection of financial security, and classification of environmental liabilities. Based on the severe financial difficulty that oil sands operators are presently facing, changes to the reclamation liability financial assurance regime need to weigh the government's desire to limit the cost of reclamation on taxpayers (thereby increasing the chance of reclamation) with the deterrent effect of being forced to post large amounts of security for reclamation many years in the future.

The MFSP was a radical reconfiguration of how financial assurance for Alberta reclamation liabilities is collected. Instead of requiring mine operators to post the amount of security for their reclamation liabilities in the upcoming year (which would be minimal for 
long-lifespan mines), the AER created a baseline approach to posting security which would increase if the operator has (1) MFSP assets less than three times larger than its MFSP liabilities ("Asset Safety Factor Deposits"); (2) is less than 15 years from the end of its reserves ("Operating Life Deposits"); or (3) is not following its operator proposed, but AER approved targeted reclamation plans (“Outstanding Reclamation Deposit"). ${ }^{198}$

Issues under the prior reclamation liability security regime were substantially decreased but not fully resolved. For example, while the legislation lacks clear guidance on what operators need to factor into reclamation liabilities, the AER website, July 2015 Auditor General Report, and AER Directives have increased the amount of public information regarding what is assessed. Moreover, while the company's own self-assessment of its liabilities does not require a certified accountant under the legislation per se, the requirement that a CEO must sign off on the assessment as well as the AER Directive's clear statement that only qualified professionals can perform the assessment limits the risk of negligently compiled assessments. However, it is still advisable that the government not rely on industry self-reporting and provide a public per mine breakdown of reclamation liability security per mined hectare.

There may still be a risk that oil sands operators are posting insufficient security. According to the AER, the MFSP is grounded in reclamation costs in the $\$ 45,000$ to $\$ 75,000$ per hectare range, in line with actual reclamation costs of $\$ 10,000$ to $\$ 250,000$ per hectare. Despite this, based on limited public information, this article found that some operators were posting security in the $\$ 12,000$ to $\$ 13,000$ per mined hectare range. However, the Auditor General of Alberta's reports (based on confidential information) have shifted in tone, saying that the current regime is sufficient and in the monitoring stage. It is troubling that environmental agencies are still granting new mine approvals even if reclamation of that land is not presently feasible based on current technology.

Asset retirement obligations are a financial accounting requirement for publicly listed corporations. This article examined the different liability allocations in AROs versus the MFSP. Ultimately, it suggested that the MFSP liabilities should be disclosed separately under AROs, due to the larger consequences a company has for making material misstatements under corporate and securities legislation. This should be qualified by the fact that AROs do not disclose all realizable liabilities. Due to the vague wording of the legislation, many broader environmental liabilities are still unlikely to be captured under the MFSP or AROs.

Lastly, there is a small but significant risk that oil sands assets may become stranded, threatening the sufficiency of the MFSP and the assets from which the government's financial assurance is derived. Some reliable sources have estimated this risk could be as high as 40 to 60 percent of market cap. However, investors are likely aware of this risk and have priced the current risk in the range of 1.5 to 2 percent. Divestment campaigns are unlikely to have a large, direct impact on fossil fuel companies' equity, debt, or share price. However, stigmatization, particularly if it results in restrictive legislation, may result in a large decrease in a company's valuation. Permanent depression of a stock price can occur if 
asset stranding risks or divestment campaigns lower the probability of a firm meeting future net cash flows.

Oil sands are at a heightened risk for asset stranding compared to the industry as a whole. This is largely due to its carbon intensive process, high cost of production compared to conventional sources of crude oil, technological difficulties, and comparatively difficult political environment. The industry has already shown that it is susceptible to market shocks. Moreover, securities regulators are closely assessing how companies evaluate risk in the oil sands. Complete fossil fuel asset stranding is unlikely to occur but a carbon tax is likely, which will reduce demand and affect firm prices.

The MFSP intentionally does not account for large market fluctuations. Forms of posted security, such as reliance on letters of credit, are problematic only if there is a mass bankruptcy in the oil sands, which would present larger problems for Canada's economy. The risk of asset stranding should be factored into the MFSP's assessment of the lifespan of a mine.

Ultimately, this article concludes with several recommendations. One, the government should increase the transparency of the factors the AER bases its security on, on a per mine basis. Two, the government should disclose each licensee's posted security amount, their percentage stake in each oil sands project, the classification of the previous ecosystem (for example, wet or dry), as well as the total developed hectare amount for each oil sands mine. Third, the government should review which environmental liabilities are and are not included in reclamation definitions, erring on the side of environmental protection where there is ambiguity. And finally, the government should consider whether the current method of collecting security is appropriate considering the increasing international trend of environmental regulation as well as Canada's domestic and international climate commitments. 
[this page is intentionally blank] 